\title{
Vector competence of pre-alpine Culicoides (Diptera: Ceratopogonidae) for bluetongue virus serotypes 1, 4 and 8
}

\author{
Anca loana Paslaru', Alexander Mathis ${ }^{1}$, Paul Torgerson $^{2}$ and Eva Veronesi ${ }^{1 *}$
}

\begin{abstract}
Background: Bluetongue disease, caused by bluetongue virus serotype 8 (BTV-8), appeared for the first time in the northern part of Europe in 2006, and subsequently rapidly spread causing severe economic losses to the farming industry. The implicated vectors of BTV in Europe are Culicoides species within the subgenus Avaritia (C. chiopterus, C. dewulfi, C. obsoletus and C. scoticus). Epidemiological data from Switzerland have shown that BTV, whose spread was eliminated at an early stage by vaccination campaigns, had not been circulating among livestock at higher altitudes where other species dominate the Culicoides fauna. In this study, we investigated the extent that Culicoides spp. prevailing at higher altitudes (mainly C. grisescens) can act as vectors for BTV.

Methods: Culicoides were collected at farms in the pre-alpine region (two sites at $1550 \mathrm{~m}$ above sea level, masl, referred to as pre-alpine l; one site at 2030 masl, pre-alpine II) and, for comparative purposes, from the Swiss Plateau (one site, 650 masl). They were fed on bovine blood/BTV suspensions (BTV-1, 4 or 8) and incubated for eight days under a fluctuating temperature regime $\left(13-25^{\circ} \mathrm{C}\right.$, mean $\left.19^{\circ} \mathrm{C}\right)$, reflecting a mid-summer warm spell in the pre-alpine region. Susceptibility to BTV transmission was assessed from head homogenates by RT-qPCR and virus isolation.

Results: Overall, 9196 female Culicoides were exposed to the three BTV strains through an artificial membrane, with feeding rates of $14-27 \%$. Survival rates of blood-engorged Culicoides females at eight days post-infection depended on both virus serotype and altitude of origin. Virus dissemination $\left(C_{q} \leq\right.$ the cut-off value as determined by serial virus dilutions) was confirmed only for BTV-1 in C. scoticus (dissemination efficiency 22.5\%; 9/40) and C. obsoletus (5.6\%; 1/18) from the Swiss Plateau area. There was no strong evidence of susceptibility to infection for Culicoides from the pre-alpine area when fed with all BTV strains (BTV-1, 4 and 8).

Conclusions: This study confirms the susceptibility of C. scoticus and C. obsoletus to BTV-1 infection, including under cooler temperatures. Culicoides grisescens, which is highly abundant at higher altitudes, cannot be considered a potential vector under these temperature conditions.
\end{abstract}

Keywords: Bluetongue virus, Culicoides, Vector competence, Dissemination efficiency, Fluctuating temperature

\section{Background}

Biting midges of the genus Culicoides (Diptera, Ceratopogonidae) are responsible for the transmission of bluetongue virus (BTV) and Schmallenberg virus (SBV) [14]. BTV (serotype 8) appeared in the northern and western part of Europe for the first time in 2006 [5, 6]; it rapidly spread and caused enormous damage to the farming

\footnotetext{
* Correspondence: eva.veronesi@uzh.ch

${ }^{1}$ National Centre for Vector Entomology, Institute of Parasitology, Vetsuisse

Faculty, University of Zürich, Zürich, Switzerland

Full list of author information is available at the end of the article
}

industry in many affected countries $[7,8]$. Intensive vaccination campaigns against BTV-8 were initiated [9-11], but BTV-8 has recently re-emerged in these areas [12]. Other BTV serotypes are circulating in eastern Europe [13] or in the Mediterranean countries (regularly updated maps of Europe showing the areas and the serotypes of circulating BTV are given on the Animal Diseases and Control Measures sections of the European Commission website.

Culicoides species within the subgenus Avaritia [Culicoides chiopterus (Meigen), Culicoides dewulfi 
(Goetghebuer), Culicoides obsoletus (Meigen), Culicoides scoticus (Downes \& Kettle)] have been implicated as the main vectors of BTV in Europe [14-16], as inferred from high abundance and from virus isolation from specimens at places of virus transmission [17-20]. Furthermore, single experimental assays have confirmed the susceptibility of $C$. obsoletus and C. scoticus to BTV-8 [21]. Species of the subgenus Avaritia, particularly those of the Obsoletus complex (C. obsoletus and C. scoticus) are also prevalent (up to $>95 \%$ of collected Culicoides) in Switzerland up to altitudes of around 1100 meters above sea level (masl), whereas C. chiopterus and $C$. dewulfi were found up to this altitude but in very small numbers [22-24]. At higher altitudes, however, other species, particularly of the subgenus Culicoides [overwhelmingly Culicoides grisescens (Edwards)] dominate the Culicoides fauna, representing around $50 \%$ of the midges at 1300 masl and $>85 \%$ at 2000 masl [22, 24, 25].

Epidemiological data from Switzerland have shown that BTV, whose transmission was eliminated at an early stage by vaccination campaigns [9], was not circulating among livestock at higher altitudes. However, investigations of free-ranging ruminants revealed a PCR-positive chamois originating from the Engadin valley at 2000 masl [26]. Furthermore, the highest altitude where a proven transmission of SBV has occurred in Switzerland is Lenzerheide (canton Grisons) at around 1500 masl (Dr C. Nathues, Federal Food Safety and Veterinary Office, Bern, Switzerland, personal communication). Thus, transmission of Culicoides-borne viruses at higher altitude appears possible, but it is neither clear which Culicoides species are involved nor whether such transmission could regularly occur under average summer conditions or only exceptionally under warm conditions. Ceratopogonidae of higher altitudes have received very little attention so far, and virtually nothing is known about their role in the transmission of BTV $[2,27]$. Whereas monitoring activities in Switzerland included altitudes up to 2100 masl [22, 24, 25], the corresponding activities in other European countries were limited to altitudes below 1400 masl: Sicily 1400 m, Bulgaria 1270 m, France 1200 m, Austria 1190 m, central Italy $1184 \mathrm{~m}$, Spain $1006 \mathrm{~m}$ [24, 28, 29]. In all cases light-suction trap collections were dominated by midges of the subgenus Avaritia. The capability of an arthropod species to act as a vector for a pathogen (vector competence) is related to several intrinsic and extrinsic factors $[30,31]$. This is usually investigated with experiments run under various constant temperature regimes. However, it has recently been demonstrated [32, 33] that daily temperature fluctuations can lead to higher infection/ transmission rates in insect vectors compared to constant temperatures. This is of great importance for assessing the probability of pathogen transmission in areas with climates that are marginal for this to occur.
With regard to BTV (there is no corresponding data for SBV), experimental work has shown that the minimal temperatures for these viruses to propagate in midges, which is a prerequisite to infect the salivary glands before transmission to a new host occurs, is around $12{ }^{\circ} \mathrm{C}$ but slightly varies among the serotypes [34, 35]. For instance, BTV-1 and BTV-9 replicated at a constant temperature of $12{ }^{\circ} \mathrm{C}$, whereas BTV-4 and BTV-8 barely amplified at temperatures below $15{ }^{\circ} \mathrm{C}$ [36]. The average temperatures are in this range at higher altitudes in Switzerland (1600 masl) in the summer months July and August (climate normals Davos, www.meteoswiss.admin.ch).

In this study, we investigated whether and to what extent the Culicoides that prevail at higher altitudes can act as vectors for BTV. Culicoides were collected from pre-alpine area (1550 and 2030 masl) and, for comparative purposes, from the Swiss Plateau area (650 masl). They were orally exposed to three BTV strains (BTV-1, BTV-4 or BTV-8) and incubated under a fluctuating temperature regime $\left(13-25^{\circ} \mathrm{C}\right.$, mean $\left.19{ }^{\circ} \mathrm{C}\right)$, reflecting a mid-summer warm spell in the pre-alpine region (www.meteoswiss.ad min.ch). Specimens with fully disseminated virus (i.e. positive heads) were considered potentially competent for BTV transmission since salivary gland barriers have not been described for Culicoides species [37].

\section{Methods}

\section{Study sites and Culicoides trapping}

Collections of Culicoides biting midges were made at farms in two areas in Switzerland, one in the Swiss Plateau (one site, 650 masl), the other in the pre-alpine region (two sites at around 1550 masl, referred to as pre-alpine I; one site at $2030 \mathrm{masl}$, referred to as pre-alpine II) (Table 1). Insects were trapped alive as described [38]. The light traps were operated from approximately $1-2 \mathrm{~h}$ before sunset to $1-2 \mathrm{~h}$ after sunrise, between June and October 2015-2017. Wet cotton pads were placed around the cages during transportation to the laboratory where the cages were transferred to incubators (Panasonic MIR-154, Gunma, Japan) with a

Table 1 Areas and features of the sites where Culicoides were collected

\begin{tabular}{|c|c|c|c|}
\hline Area & Site (altitude, masl) & Coordinates & $\begin{array}{l}\text { Predominant animal } \\
\text { species at farm }\end{array}$ \\
\hline Swiss Plateau & Adlisberg (650) & $\begin{array}{l}47.22298^{\circ} \mathrm{N} \\
008.34565^{\circ} \mathrm{E}\end{array}$ & Horses \\
\hline \multirow[t]{2}{*}{ Pre-alpine I } & Davos Wolfgang (1575) & $\begin{array}{l}46.82638^{\circ} \mathrm{N}, \\
009.85732^{\circ} \mathrm{E}\end{array}$ & Sheep and pigs \\
\hline & Lenzerheide (1542) & $\begin{array}{l}46.73014^{\circ} \mathrm{N}, \\
009.56091^{\circ} \mathrm{E}\end{array}$ & Horses \\
\hline Pre-alpine II & $\begin{array}{l}\text { Davos, Clavadeler } \\
\text { Alp (2030) }\end{array}$ & $\begin{array}{l}46.76650^{\circ} \mathrm{N} \\
009.81831^{\circ} \mathrm{E}\end{array}$ & Cattle \\
\hline
\end{tabular}


fluctuating temperature $\left(13-25{ }^{\circ} \mathrm{C}\right.$, mean $\left.19{ }^{\circ} \mathrm{C}\right)$ and a relative humidity of $85-90 \%$ (Fig. 1). Cotton wool pads with $10 \%$ sucrose solution were supplemented.

\section{Insect identification}

Culicoides were first morphologically classified to group or complex level using an online identification key [39], whereas species identification was achieved on thoraxes by using matrix-assisted laser desorption/ionization time-of-flight mass spectrometry (MALDI-TOF MS) exactly as described [24]. Briefly, thoraxes with wings were manually homogenized in $7 \mu$ l of formic acid (25\%). One microliter was spotted onto a steel target plate in duplicates, air-dried at room temperature and overlaid with $1 \mu \mathrm{l}$ of SA Matrix (20 mg sinapic acid in $300 \mu \mathrm{l}$ acetonitrile, $200 \mu \mathrm{l}$ distilled water and $1.5 \mu \mathrm{l}$ trifluoracetic acid; Sigma-Aldrich, Buchs, Switzerland). The plates were sent to Mabritec SA (Riehen, Switzerland) by overnight courier. Protein mass fingerprints were obtained using a MALDI-TOF Mass Spectrometry Axima ${ }^{\mathrm{TM}}$ Confidence machine (Shimadzu-Biotech Corp., Kyoto, Japan) and subjected to automated identification against the in-house database containing validated biomarker mass sets of 14 Culicoides species. Alternatively, PCR and sequencing were done as follows: DNA from abdomens was isolated by using the DNA mini kit following the manufacturer's instruction (Qiagen, Hilden, Germany), with proteinase $\mathrm{K}$ incubation periods between $4 \mathrm{~h}$ and overnight. PCRs targeting the mitochondrial cytochrome $c$ oxidase subunit $(\operatorname{cox} 1)$ were done using the the AmpliTaq Gold 360 Master Mix (Applied Biosystems, Thermo Fisher Scientific, Reinach Switzerland) with primers C1-J-1718 and C1-N-2191 mod [40] and, in case of unsuccessful amplifications, with primers LCO1490 and HCO2198 [41]. Each PCR round included the positive and negative control. Amplifications were done in a PTC-200 Peltier Thermal Cycler (Bio-Rad Laboratories AG, Reinach, Basel, Switzerland) with a profile including a Taq DNA polymerase

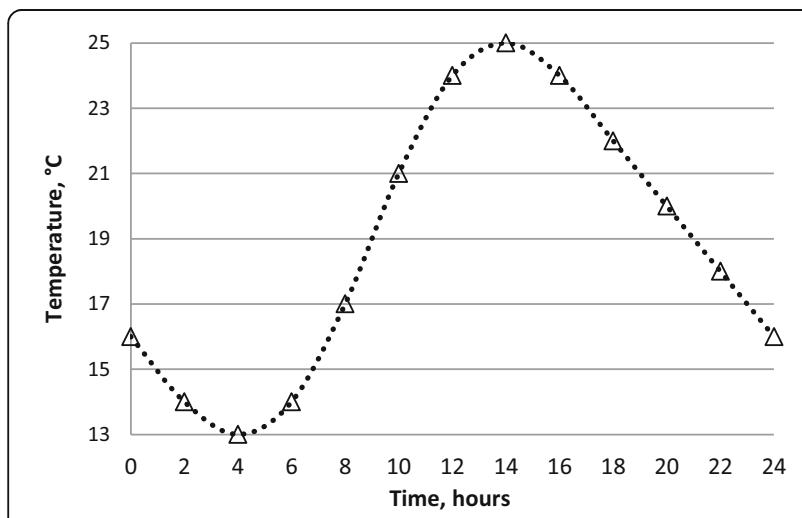

Fig. 1 Fluctuating temperature regime during incubation of Culicoides activation step $\left(95^{\circ} \mathrm{C}\right.$ for $15 \mathrm{~min}$ ), 35 cycles at $95^{\circ} \mathrm{C}$ for 30 s annealing at $50{ }^{\circ} \mathrm{C}$ for $30 \mathrm{~s}$ and extension at $72{ }^{\circ} \mathrm{C}$ for 60 s. A final elongation step at $72{ }^{\circ} \mathrm{C}$ for $10 \mathrm{~min}$ was included. DNA concentration was measured using a Nanodrop photometer (NanoDrop products, Wilmington, USA). Sequencing of amplicons after purification with the minelute PCR purification kit (Qiagen), was done by a private company (Synergene GmbH, Schlieren, Switzerland).

\section{Virus}

The three BTV strains used for oral inoculation of Culicoides were kindly provided by the Centre for Virus Research (Glasgow, UK): BTV-1 (RSArrrr/01, BSR 1 passage) [42], BTV-4 (RSArrrr/04, BSR 1 passage) [43], and BTV-8 (NET06, $\mathrm{KC}_{1} / \mathrm{BHK}_{3}$ passage) [42]. The viruses were further propagated on Vero cells (African green monkey kidney cells), kindly supplied by the Institute of Virology and Immunology (Mittelhäusern, Switzerland) and/or KC cells (C. sonorensis embryonal cells), kindly provided by The Pirbright Institute (Pirbright, UK). Briefly, Vero cells were grown in $150 \mathrm{~cm}^{2}$ cell culture flasks containing Glasgow Minimum Essential Media (GMEM) (Gibco, Thermo Fisher Scientific, Reinach, Switzerland) supplemented with $1 \%$ antibiotics and fungizone $(1000 \mathrm{IU} / \mathrm{ml}$ penicillin/streptomycin; $4 \mu \mathrm{g} / \mathrm{ml}$ amphotericin; Gibco, Thermo Fisher Scientific) (GMEM complete) and $10 \%$ foetal calf serum (FCS, Bioconcept, Allschwil, Switzerland) (GMEM growth media). Flasks were incubated at $37{ }^{\circ} \mathrm{C}$ with $5 \% \mathrm{CO}_{2}$ until reaching a confluence of $75-80 \%$ (approximately $24 \mathrm{~h}$ ). The media was then removed and $200 \mu \mathrm{l}$ of BTV viral stock was added. After $30 \mathrm{~min}$ at room temperature, $40 \mathrm{ml}$ of GMEM maintenance media (GMEM complete supplemented with $2 \%$ FCS) were added and the flasks incubated at $37{ }^{\circ} \mathrm{C}$ with $5 \% \mathrm{CO}_{2}$ until the observation of cytopathic effect (CPE) (maximum seven days). Virus titres of supernatants were calculated by titration of 10 -fold serial dilutions in 96-well plates as described [44].

$\mathrm{KC}$ cells were grown in $75 \mathrm{~cm}^{2}$ cell culture flasks containing Schneider's Drosophila Media (Gibco, Thermo Fisher Scientific) supplemented with $1 \%$ antibiotics and fungizone (Schneider's complete media) and 10\% FCS (Schneider's growth media). After seven days of incubation at $27{ }^{\circ} \mathrm{C}$ without $\mathrm{CO}_{2}$, the supernatant was removed and $100 \mu \mathrm{l}$ of BTV viral stock was added to the cells, together with $30 \mathrm{ml}$ of Schneider's complete media with $2 \%$ FCS (Schneider's maintenance media). The flasks were incubated for seven days at $27{ }^{\circ} \mathrm{C}$, and virus infectivity investigated by titration of 10 -fold serial dilutions of the supernatants in 96-well plates layered with $\mathrm{KC}$ cells according to the protocol described above for Vero cells, but using Schneider's complete media instead of GMEM. Since KC cells do not show CPE, viral RNA was extracted from the wells after seven days of incubation, 
and reverse transcription quantitative polymerase chain reaction (RT-qPCR) (see below) was performed to calculate the tissue culture infectious dose $\left(\mathrm{TCID}_{50 /} \mathrm{ml}\right)$ [45]. Finally, $\mathrm{TCID}_{50} / \mathrm{ml}$ was transformed into $\mathrm{PFU} / \mathrm{ml}$, and a standard curve for each BTV strain was generated by conversion into PFU of viral RNA $\left(\mathrm{C}_{\mathrm{q}}\right.$ values) determined for each serial dilution.

\section{Vector competence}

\section{Culicoides oral exposure to BTV strains}

Three days post-collection, the insects were starved for one day and, at day 5 , the live ones were transferred, using a mouth aspirator, to a paper cup covered with a net. The insects were anesthetised at $-20^{\circ} \mathrm{C}$ for $2-3$ min and transferred (maximum 300 individuals/chamber) into a "feeding chamber" as previously used for feeding C. imicola in South Africa [46], but with Nescofilm50 MMx 40M (Alfresa Pharma Corporation, Osaka, Japan) instead of chicken skin as a membrane (see Additional file 1: Figure S1). The insects were exposed for 30-45 minutes to heparinised bovine blood (obtained from a local abattoir) spiked with virus at a temperature of $25 \pm 4{ }^{\circ} \mathrm{C}$. They were then anesthetised as described above and gently transferred into a precooled $\left(-20{ }^{\circ} \mathrm{C}\right)$ glass Petri dish placed on top of an icepack element inside a glove box. The engorged Culicoides females were sorted and counted under a stereomicroscope and incubated for eight days in cardboard boxes [Adelphi healthcare packaging 4 oz. (162 ml) A.P.D Deep, Hawards Heath, UK] (maximum 100 females/box) under the fluctuating temperature regime shown in Fig. 1. All Culicoides surviving the eight days incubation period were individually stored in sterile $1.5 \mathrm{ml}$ Eppendorf tubes at $-80{ }^{\circ} \mathrm{C}$ until further investigation. The non-engorged insects were killed and the Culicoides specimens counted. One blood-fed female (Day 0) and an aliquot of the blood used for feeding were collected for each meal and strain and stored at $-80^{\circ} \mathrm{C}$ for further analyses.

A preliminary test evaluating Culicoides feeding rates in relation to different ratios of blood to cell culture media (DMEM) was carried out with midges from the Swiss Plateau site at day five post-collection.

Feeding rates of midges on different ratios (1:1, 2:1, 9:1) of bovine blood to virus cell culture media (DMEM) were evaluated with the feeding chamber in triplicate experiments following 3 days of acclimatization and $24 \mathrm{~h}$ of starvation.

\section{Culicoides dissection and homogenisation}

Homogenates of individual heads were used to investigate virus dissemination and thoraxes for species identification (described above). Briefly, heads were removed by using sterile needles (Fine-Ject, Tuttingen, Germany) and transferred into $1.5 \mathrm{ml}$ Eppendorf tubes containing $100 \mu \mathrm{l}$ of GMEM growth media (see above). For homogenization, Culicoides were either manually processed for $30 \mathrm{~s}$ using sterilised polypropylene pestles (Sigma-Aldrich, Gillingham, Dorset, UK) mounted to a motorized grinder (Micro Handrührer, Carl Roth, Karlsruhe, Germany) or homogenized for $2 \times 30 \mathrm{~s}$ with $3 \mathrm{~mm}$ diameter stainless steel ball bearings using the Tissue Lyser II Instrument (Qiagen) as previously described [47]. After homogenization, each sample was filled up with $900 \mu \mathrm{l}$ of Glasgow MEM giving a final volume of $1 \mathrm{ml} /$ homogenate. All tubes were then vortexed and centrifuged for $5 \mathrm{~m}$ at $13000 \times \mathrm{g}$. Aliquots were immediately processed for viral RNA extraction and the rest of the homogenates was kept at $4{ }^{\circ} \mathrm{C}$.

\section{Virus detection and quantification RNA extraction and $P C R$}

Nucleic acid extraction was carried out using the QIAamp viral RNA mini kit (Qiagen) following the manufacturer's instructions (elution volume $45 \mu \mathrm{l}$ ). RNA was initially isolated from pools of maximum five individual head homogenates $(100 \mu \mathrm{l}$ each), and viral RNA was extracted from each individual homogenate in case of a positive RT-qPCR on the RNA from the pooled samples. RNA was amplified by RT-qPCR in a CFX96 Touch real-time system (Bio-Rad Laboratories, Cressier, Switzerland). The $25 \mu \mathrm{l}$ reactions included $5 \mu \mathrm{l}$ RNA, $0.5 \mu \mathrm{l}$ of each primer and $1 \mu \mathrm{l}$ probe ( $20 \mu \mathrm{M}$ and $5 \mu \mathrm{M}$, respectively), $4.8 \mu \mathrm{l}$ of RNase-free $\mathrm{H}_{2} \mathrm{O}$, $12.5 \mu \mathrm{l}$ of iTaq universal probes reaction mix $(2 \times)$ (iTaq Universal probes one-step kit, Bio-Rad Laboratories, Hercules, California, USA) and $0.7 \mu \mathrm{l}$ of iScript advanced reverse transcriptase. Primers [sense BTV_IVI_F (5'-TGG-AYA-AAG-CRA-TGT-CAA-A-3'), anti-sense BTV_IVI_R (5'-ACR-TCA-TCA-CGA-AAG-GCT-TC-3')] and probe BTV_IVI_P (5'-FAM-ARG CTG CAT TCG CAT CGT ACG C-3'-BHQ-1)] were kindly supplied by the Institute of Virology and Immunology (Mittelhäusern, Switzerland). As positive and negative PCR controls, $5 \mu \mathrm{l}$ of extracted BTV RNA from virus stock or RNase-free $\mathrm{H}_{2} \mathrm{O}$, respectively, were used. The method used in our tests is an adaption from [48] capable of detecting all BTV serotypes and strains currently circulating and targeting BTV segment 10 (NS3). The reactions were run with the following cycle conditions: 1 cycle for reverse transcription (10 min at $50{ }^{\circ} \mathrm{C}$ ), 1 cycle for reverse transcriptase inactivation and Taq activation $\left(2\right.$ minutes at $\left.95{ }^{\circ} \mathrm{C}\right)$, and 50 amplification cycles $\left(15 \mathrm{~s}\right.$ at $95^{\circ} \mathrm{C}, 30 \mathrm{~s}$ at $56{ }^{\circ} \mathrm{C}$, and $30 \mathrm{~s}$ at $\left.72{ }^{\circ} \mathrm{C}\right)$.

In order to identify the species that were susceptible for each BTV strain, all the survived females fed with BTV-1, BTV- 4 and BTV-8 that came up positive by RT-qPCR were processed by MALDI-TOF MS or PCR/ sequencing. Due to time and mainly budget restriction issues, species identification was not carried out for all the remaining specimens (RT-qPCR negative females). Thus, all the negative females from the BTV-1 
experiments were identified, whereas subsamples were analysed from the corresponding BTV-4 and BTV-8 experiments (more than 100 negative females/strain).

\section{Virus isolation}

All the females that were positive by RT-qPCR were also tested for the presence of infectious virus particles by virus isolation on Vero cells using $25 \mathrm{~cm}^{2}$ cell culture flasks following the same protocol described above for virus propagation and amplification. Briefly, $100 \mu \mathrm{l}$ of head homogenate was inoculated onto the $25 \mathrm{~cm}^{2}$ culture flasks layered with $70-80 \%$ confluent Vero cells, followed by incubation for $30 \mathrm{~min}$ at room temperature. Then GMEM maintenance media was added to a final volume of $8 \mathrm{ml}$ per flask. After incubation for 7 days at $37^{\circ} \mathrm{C}$ with $5 \% \mathrm{CO}_{2}$, a further (blind) passage was carried out by inoculation of $100 \mu \mathrm{l}$ of the supernatants of passage $1\left(\mathrm{~V}_{1}\right)$ into new 25 $\mathrm{cm}^{2}$ flasks containing Vero cells and amplified as described above, generating passage $V_{2}$. When CPE were observed, titration of the flask supernatant was carried out as described above for viral strains. If no CPE was detected after two passages, no further tests were performed with the sample.

\section{Statistical analysis}

Data on dissemination (positive Culicoides heads) for the BTV strains were analysed using a generalized linear model with a Tweedie link to model positive PCR values as a quantitative continuous distribution with an excess of zeros (or negative PCR). The data were also analysed using a binomial link function with positive and negative PCR. The analyses were performed using R (https:// www.R-project.org/). A multivariable logistic additive regression model was used to analyse whether altitude of the sampling site or the strain had an (non-linear) impact on the survival rate of blood-fed Culicoides. Statistical differences on feeding rate according to dilution factors were investigated using Fisher's exact test. The significance threshold was set at 0.05 .

\section{Results}

\section{Oral feeding}

To evaluate feeding rates, a total of 690 midges collected on a single occasion at the Swiss Plateau site were used. Thus, the feeding rates increased with decreasing blood dilution, with a statistically significant difference between the feeding rates on the blood meals with the 1:1 and 1:9 (Fisher's exact test, $P=0.003$ ) (Table 2). Feeding rates of the vector competence experiments (see Table 3) were done with blood-meals with ratios $1: 1$ or $2: 1$ (see below) and were in the range of $14-27 \%$ (mean of $18 \%$ ).

\section{Virus inocula}

The final inoculum of BTV-1 was obtained after three passages on Vero cells (BTV-1 $\mathrm{V}_{3}$; titre 5.75
Table 2 Feeding rates of Swiss Plateau Culicoides after exposure to different ratios of heparinised bovine blood to cell culture medium (DMED) in three replicates (Fisher's exact test)

\begin{tabular}{lll}
\hline Ratio & $\begin{array}{l}\text { No. of Culicoides exposed } \\
\text { to blood/engorged (\%) }\end{array}$ & Mean feeding rate (\%) \\
\hline $1: 1^{\text {a }}$ & $69 / 9(13)$ & 14 \\
& $120 / 8(7)$ & \\
& $80 / 14(18)$ & 19 \\
$2: 1^{\text {ab }}$ & $86 / 6(7)$ & \\
& $104 / 26(25)$ & \\
& $82 / 17(21)$ & 28 \\
$9: 1^{\text {b }}$ & $84 / 12(14)$ \\
& $32 / 15(47)$ & \\
& $33 / 14(42)$ &
\end{tabular}

Notes: Culicoides were exposed to blood meal at day 5 post-collection (after incubation for 3 days with access to $10 \%$ sucrose and $24 \mathrm{~h}$ starvation). The feeding device of [39] with Nescofilm as membrane was used

${ }^{\mathrm{ab}} \mathrm{P}=0.003$

$\left.\log _{10} \mathrm{TCID}_{50} / \mathrm{ml}\right)$, while the inoculum of BTV-4 and BTV-8 originated from several consecutive passages through C. sonorensis (KC) and Vero cells (BTV-4 $\mathrm{KC}_{3} \mathrm{~V}_{4}$, titre $6.75 \log _{10} \mathrm{TCID}_{50} / \mathrm{ml} ; \mathrm{BTV}-8 \mathrm{KC}_{3} \mathrm{~V}_{6}, 6.75$ $\left.\log _{10} \mathrm{TCID} \mathrm{D}_{50} / \mathrm{ml}\right)$. Standard curves of the $\mathrm{C}_{\mathrm{q}}$ values versus the converted PFU values obtained from viral RNA extracted from the serial dilutions of each BTV inoculum (see Additional file 2: Figure S2) showed high correlation coefficients for the virus stocks of all three strains (BTV-1, $R^{2}=0.966$; BTV-4, $R^{2}=0.996$; BTV-8, $R^{2}=0.999$ ).

\section{Vector competence}

\section{Culicoides oral exposure to BTV strains}

Overall, 9196 field-collected Culicoides were exposed in several experiments to blood spiked with BTV-1 (final titre $5.5 \log _{10} \mathrm{TCID}_{50} / \mathrm{ml}$, ratio blood to virus cell culture supernatant 1:1), BTV-4 or BTV-8 (final titres 6.25 $\log _{10} \mathrm{TCID}_{50} / \mathrm{ml}$, ratio $2: 1$ ). A total of 4431 exposed midges from the pre-alpine areas I and II yielded 742 (17\%) engorged Culicoides females out of which 238 (32\%) survived the incubation period of eight days and were analysed for the presence of virus (Table 3). The blood-feeding rate $(17 \% ; 809 / 4765)$ and the survival rate (38\%, total 310 specimens) of midges from the Swiss Plateau were similar (Table 3).

A multivariable additive logistic regression demonstrated that the survival rate (Fig. 2) was associated with both strain (additive logistic model, $t=6.8, P=0.002$ ) and altitude (additive logistic model, $t=11.4, P=0.003$ ). Culicoides infected with BTV-8 had a better survival rate at each altitude $(P<0.0005)$. The altitude was not a linear effect, i.e. midges from the intermediate site had the highest survival rates with all BTV serotypes. 
Table 3 Description of Culicoides populations from different areas screened for virus presence in the head (dissemination) after exposure to blood spiked with bluetongue virus (BTV-1, BTV-4 or BTV-8) ${ }^{a}$

\begin{tabular}{|c|c|c|c|c|c|}
\hline \multirow[t]{2}{*}{ Area } & \multirow{2}{*}{$\begin{array}{l}\text { BTV } \\
\text { strain }\end{array}$} & \multirow{2}{*}{$\begin{array}{l}\text { No. Culicoides: } \\
\text { blood-fed/examined } \\
\text { for BTV/positive } \\
\text { for BTV }{ }^{\mathrm{b}} \text { (infection rate, \%) }\end{array}$} & \multicolumn{3}{|l|}{ Species $^{c}$} \\
\hline & & & $\begin{array}{l}\text { RT-qPCR positive species } \\
\text { (\% of all specimens tested) }\end{array}$ & $C_{q}$ range & $\begin{array}{l}\text { RT-qPCR negative species } \\
\text { (\% all specimens tested) }\end{array}$ \\
\hline \multirow{10}{*}{$\begin{array}{l}\text { Swiss Plateau } \\
\text { (650 masl) }\end{array}$} & \multirow[t]{3}{*}{ BTV-1 } & \multirow[t]{3}{*}{ 160/61/27 (44) } & 24 C. scoticus (39) & $33.2-41.3$ & 16 C. scoticus (26) \\
\hline & & & 2 C. obsoletus (3) & $35.7-39.6$ & 16 C. obsoletus (26) \\
\hline & & & 1 C. pallidicornis (2) & 39.6 & 2 unknown (3) ${ }^{d}$ \\
\hline & \multirow[t]{4}{*}{ BTV-4 } & \multirow[t]{4}{*}{ 242/104/2 (2) } & \multirow[t]{4}{*}{2 C. scoticus (3) } & \multirow[t]{4}{*}{$45.4-48.9$} & 46 C. obsoletus (75) \\
\hline & & & & & 7 unknown (11) \\
\hline & & & & & 5 C. scoticus (8) \\
\hline & & & & & 1 C. chiopterus (2) ${ }^{d}$ \\
\hline & \multirow[t]{3}{*}{ BTV-8 } & \multirow[t]{3}{*}{ 407/145/3 (2) } & 2 C. obsoletus (7) & $40.2-40.9$ & 20 C. obsoletus (67) \\
\hline & & & 1 C. pallidicornis (3) & 39.9 & 6 C. scoticus (20) \\
\hline & & & & & 1 C. punctatus (3) ${ }^{\mathrm{d}}$ \\
\hline \multirow{9}{*}{$\begin{array}{l}\text { Pre-alpine } \\
\Gamma^{\prime}(\approx 1550 \text { masl) }\end{array}$} & \multirow[t]{7}{*}{ BTV-1 } & \multirow[t]{7}{*}{ 239/64/1 (1.5) } & \multirow[t]{7}{*}{1 C. reconditus-like (1.5) } & \multirow[t]{7}{*}{40.3} & 28 C. grisescens II (44) \\
\hline & & & & & 23 C. obsoletus (36) \\
\hline & & & & & 4 C. grisescens I (6) \\
\hline & & & & & 4 unknown (6) \\
\hline & & & & & 2 C. scoticus (3) \\
\hline & & & & & 1 C. pulicaris (1.5) \\
\hline & & & & & 1 C. deltus (1.5) \\
\hline & BTV-4 & 107/35/0 (0) & & & nd \\
\hline & BTV-8 & 24/18/0 (0) & & & nd \\
\hline \multirow{3}{*}{$\begin{array}{l}\text { Pre-alpine II } \\
\text { (2030 masl) }\end{array}$} & BTV-1 & $2 / 1 / 0(0)$ & & & 1 C. grisescens II (100) \\
\hline & BTV-4 & 168/17/0 (0) & & & nd \\
\hline & BTV-8 & 202/103/0 (0) & & & nd \\
\hline
\end{tabular}

Abbreviations: unknown, species not included in database; nd, not done

${ }^{\text {a Titres }}\left(\log _{10} \mathrm{TCID}_{50} / \mathrm{ml}\right)$ of the blood meals were 5.50 (BTV-1) or 6.25 (BTV-4, BTV-8). Engorged females were incubated for eight days under a fluctuating temperature regime $\left(13-25^{\circ} \mathrm{C}\right.$, average $\left.19^{\circ} \mathrm{C}\right)$

${ }^{\mathrm{b}} \mathrm{C}_{\mathrm{q}}$ values $<50$

'Species identified by MALDI-TOF MS analyses

${ }^{\mathrm{d}}$ All specimens examined for BTV dissemination identified to species level (experiments with BTV-1, collected in September-October) or proportions with randomly selected specimens (biting midges from experiments with BTV-4, collected in July-August, and BTV-8, collected in June)

Identified by PCR/sequencing ( $96 \%$ identity with GenBank entry of C. reconditus)

\section{Virus detection and Culicoides species}

The $\mathrm{C}_{\mathrm{q}}$ values of the blood meals used for the vector competence studies and the Day 0 females are shown in Table 4. All Day 0 females were positive for BTV, proving that virus was ingested by fully engorged Culicoides.

Overall, 33 Culicoides were positive for viral RNA exhibiting $\mathrm{C}_{\mathrm{q}}$ values ranging between 33.2 and 48.9 (see Additional file 3: Table S1). When applying a cut-off of $\mathrm{C}_{\mathrm{q}} \leq 36$ (BTV-1) and $\mathrm{C}_{\mathrm{q}} \leq 38$ (BTV-4 and BTV-8) as generated from the standard curves of the three BTV strains (see Additional file 2: Figure S2), the number of fully disseminated Culicoides is 10 (9 C. scoticus and 1 C. obsoletus), all of which originated from the Swiss Plateau area and infected with BTV-1. The overall percentage of dissemination efficiency for this population was
$16.4 \%$ (10/61), represented by $22.5 \%$ C. scoticus $(9 / 40)$ and $5.6 \%$ C. obsoletus (1/18).

The Swiss Plateau Culicoides exposed to the three viral strains originated from populations collected during different times of the season (Table 3), and their species compositions varied. Thus, the midges exposed to BTV-1 were collected late in the season (September/October) and mainly contained C. scoticus $(65.6 \% ; n=40 / 61)$ and C. obsoletus $(29.5 \% ; n=18 / 61)$. Culicoides tested for BTV-4 $(n=104)$ were collected in July-August. Further analyses of a subsample $(n=59 / 102)$ from the remaining (negative) Culicoides revealed a predominance of C. obsoletus $(75.4 \% ; n=46)$, followed by C. scoticus $(11.4 \%$; $n=7)$. The BTV-8 experiments were done with midges collected in June. Identification of the 3 specimens with detectable viral RNA (although with $\mathrm{C}_{\mathrm{q}}$ values of 


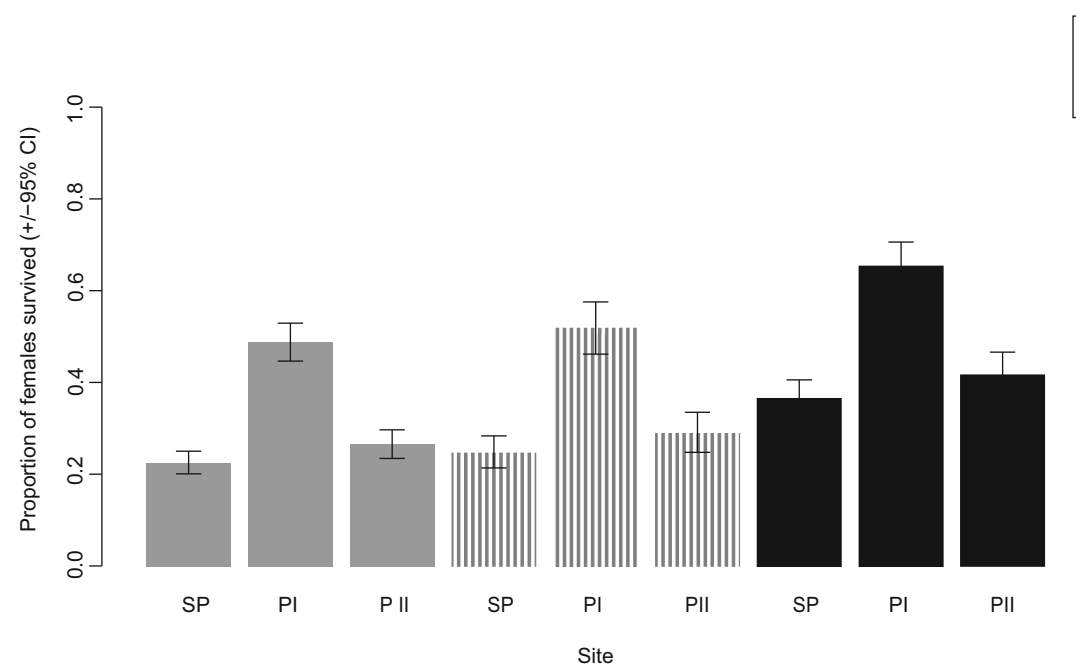

Fig. 2 Proportion ( $\pm 95 \% \mathrm{Cl}$ ) of blood-fed Culicoides that survived the 8-day incubation period after exposure to blood spiked with BTV-1, BTV-4 or BTV-8 (Table 4) according to collection site. Abbreviations: SP, Swiss Plateau at 650 masl; PI, pre-alpine sites I at 1500 masl; PII, pre-alpine site II at 2030 masl

39.9-40.9 which are slightly above the threshold of $\mathrm{C}_{\mathrm{q}} 38$ ) and 27 randomly selected out of the 142 negative ones revealed C. obsoletus as predominant species $(73.3 \% ; 22 / 30)$ followed by C. scoticus (20\%; 6/30).

Among all the females collected in the pre-alpine areas I and II that were examined for dissemination (viral RNA in the head) of BTV-1, 4 or 8 , only one gave detectable viral RNA although with a $C_{q}$ value above the cut-off $\left(C_{q} 40.3\right)$ (Table 3). This specimen [as closely related to Culicoides reconditus (Campbell \& Pelham-Clinton) by barcode sequencing, sequence identity $636 / 658$ bp (96\%) with GenBank accession no. KJ767955] originated from the pre-alpine area I and was exposed to blood spiked with BTV-1. The remaining specimens which tested negative for BTV-1 $(n=63)$ mainly belonged to $C$. grisescens $(44 \%)$ and $C$. obsoletus (36\%) (Table 3) as determined by MALDI-TOF MS.

Our study showed that BTV-4 and BTV-8 had lower rates of dissemination compared to BTV-1 (logistic regression, $z$-values $=-3.5$ and -3.9 , respectively, $P<0.001$ in both cases), and there were no significant differences between BTV-4 and BTV-8.

The quantitative study showed that Culicoides infected with BTV-4 and BTV-8 had less viral load compared to those infected with BTV-1 (generalized linear model, $t$-values $=-4.1$ and -4.6 , respectively, $P<0.001$ in both cases), whilst there were no differences between Culicoides infected with BTV-8 and BTV-4.

\section{Virus isolation}

Overall, homogenates from the heads of the 33 females with detectable viral RNA after RT-qPCR (see Additional file 3: Table S1) were screened for infectious virus particles based on a Vero cells assay. Only one was positive as observed by a cytopathic effect (CPE) after two blind passages. The female that was found positive for virus isolation was a $C$. scoticus $\left(\mathrm{C}_{\mathrm{q}} 34.8\right)$ from the Swiss Plateau which had fed on blood spiked with BTV-1. The virus titre of this female reached $6.5 \log _{10} \mathrm{TCID}_{50} / \mathrm{ml}$ after two consecutive amplifications on Vero cells $\left(\mathrm{V}_{2}\right)$.

Table 4 Bluetongue viral RNA quantified by RT-qPCR $\left(C_{q}\right)$ detected in blood used for oral infection of field-collected Culicoides and in the abdomen of individual engorged Culicoides immediately after feeding (Day 0), and species of analysed specimens identified by MALDI-TOF mass spectrometry using head and thorax

\begin{tabular}{|c|c|c|c|c|c|c|c|c|c|}
\hline \multirow[t]{2}{*}{ Area } & \multicolumn{3}{|l|}{ BTV-1 } & \multicolumn{3}{|l|}{ BTV-4 } & \multicolumn{3}{|l|}{ BTV-8 } \\
\hline & Blood & Culicoides Day 0 & Species & Blood & Culicoides Day 0 & Species & Blood & Culicoides Day 0 & Species \\
\hline \multirow[t]{2}{*}{ Swiss Plateau (650 masl) } & 24.8 & 32.8 & C. obsoletus & 26.3 & 39.0 & C. scoticus & 26.6 & 35.4 & C. obsoletus \\
\hline & 27.8 & 36.4 & C. scoticus & 26.3 & 43.4 & C. obsoletus & 22.2 & 38.9 & C. obsoletus \\
\hline \multirow[t]{2}{*}{ Pre-alpine I $(\approx 1550$ masl) } & 45.1 & 42.5 & C. pulicaris & 24.4 & 33.7 & C. grisescens ॥ & 23.2 & 32.5 & C. grisescens $\|$ \\
\hline & & & & 24.5 & 37.2 & C. obsoletus & 23.8 & 37.1 & C. obsoletus \\
\hline \multirow[t]{2}{*}{ Pre-alpine II (2030 masl) } & 28.2 & 34.4 & C. grisescens $\|$ & 25.2 & 33.7 & C. grisescens ॥ & 23.1 & 34.5 & C. grisescens II \\
\hline & & & & 23.0 & 35.7 & C. grisescens \| & & & \\
\hline
\end{tabular}




\section{Discussion}

In this study we describe vector competence traits for field-collected populations of Culicoides from pre-alpine and Swiss Plateau areas after oral exposure to three bluetongue virus strains (BTV-1, BTV-4 or BTV-8). Such experimental work has been performed by other research groups, focussing mainly on field-collected $C$. imicola which is the incriminated main BTV vector in Africa [34, 49-51]. Further such studies have also been done in C. brevitarsis and C. insignis in the USA and in Australia $[52,53]$ whereas in Europe, C. impunctatus, $C$. obsoletus, $C$. pulicaris and $C$. scoticus have been proven to be susceptible to BTV serotypes $3,4,8$ or 9 [21, 54, 55]. Other studies were also done on laboratory colonies of C. nubeculosus and C. sonorensis [54, 56-60]. Due to the huge variations in the experimental settings (Culicoides species, BTV strain, virus titre in blood meal, incubation temperature and period, etc.), the results are difficult to compare and do not allow general conclusions to be drawn [27].

The vector competence studies here presented were done under fluctuating temperature ranging between 13 and $25^{\circ} \mathrm{C}$ (mean of $19{ }^{\circ} \mathrm{C}$ ), representing a warm summer spell at the pre-alpine region. These are considerably cooler conditions than those in comparable experiments when incubation temperatures were at 23 or $25{ }^{\circ} \mathrm{C}$ [21, $54,55]$. Our results show that under these conditions Culicoides from Swiss Plateau are susceptible to BTV-1 strain infection (Table 3).

Most striking is the high overall susceptibility (Culicoides with viral RNA $\mathrm{C}_{\mathrm{q}} \leq 36$ ) of the midges from the Swiss Plateau to BTV-1 (16.4\%). The most abundant species in these populations, C. scoticus (65.6\%), had a dissemination efficiency (positive heads/all C. scoticus tested) of 22.5\% (9/40) (Table 3). High vector competence for BTV-1 has been described before for $C$. bolitinos (26.5\%) and C. sonorensis (12-20\%) whereas C. imicola and C. brevitarsis seem to be relatively refractory $[49,50,52,56]$.

The susceptibility to fully disseminated infection in our study varied among the BTV strains that we tested. However, it is also true that the number of survived Culicoides post-oral-feeding (e.g. BTV-4 infected Culicoides from the pre-alpine areas I and II) was small despite the fact that we had a considerable amount of fully engorged midges (Table 3). Although we were aware of this, the short lenght of summer season at pre-alpine altitudes inevitably affected the available period for field Culicoides trapping (July-August). This was one of our major constrains during our two-year funded project. Further studies should therefore aim to improve survival rate of blood fed Culicoides in order to confirm the lack of susceptibility we here observed for those Culicoides from pre-alpine areas (Table 3).

The higher susceptibility observed in BTV-1 might, on the one hand, be due to its adaptation to cooler temperatures. The degree and speed of replication varied for several strains of BTV investigated on a $\mathrm{KC}$ cells based assay (C. sonorensis) when infected cells were incubated at different temperatures $\left(8,10,12,15,25,30{ }^{\circ} \mathrm{C}\right)$ [36]. Indeed, BTV-1 was the only one showing a good amplification rate at temperatures as low as $12{ }^{\circ} \mathrm{C}$, while there was little indication of an increase in virus titre for BTV-4 at 21 days post-infection. Both strains comparably replicated at $25{ }^{\circ} \mathrm{C}$, reaching a plateau of $6.5 \log _{10} \mathrm{TCID}_{50} / \mathrm{ml}$ after only four days.

On the other hand, discrepancies of dissemination observed in our studies should likewise consider the Culicoides species composition in the assays. Thus, the experiments with BTV-1 with populations from the Swiss Plateau contained mainly the highly susceptible C. scoticus as shown in the present study. The corresponding experiments with midges from the pre-alpine I area, which revealed only one insect with detectable viral RNA (C. reconditus-like; $\mathrm{C}_{\mathrm{q}}$ 40.3), mainly comprised C. grisescens (cryptic species I and II, [61]) which seems to be refractory to the virus under the chosen conditions (incubation temperature and time).

Dissemination efficiency of the Swiss Plateau midges was much lower for BTV-4 and BTV-8 as compared to BTV-1, and the $\mathrm{C}_{\mathrm{q}}$ ranges were just (BTV-8) or clearly (BTV-4) above the cut-off value. As indicated above, the higher temperature requirements of these strains [36] might have contributed to this outcome. Again, the $\mathrm{C}_{\mathrm{q}}$ values in these experiments were high (see also below), and thus these interpretations need to be taken with extreme caution. Earlier experimental work revealed a similar low vector competence for BTV-8 of less than $1 \%$ for both species after incubation at $23-25^{\circ} \mathrm{C}$ for ten days [21].

There were strong variations in the population ratios of C. scoticus and C. obsoletus over the season in our experiments, and such seasonal variations have been described before [62]. As C. scoticus and C. obsoletus differ in their vector competence for BTV-1 their identification to species level, rather than referring to them as Obsoletus complex, seems essential in vector competence studies. This can be achieved by PCR/sequencing, multiplex PCRs [63], or by mass spectrometry as in the present study.

Culicoides pallidicornis was a rare species in the collections from the Swiss Plateau (2 of 152 specimens identified by mass spectrometry). Both specimens had detectable viral RNA for BTV (1 or 8 ), though with $\mathrm{C}_{\mathrm{q}}$ values slightly above the threshold (39.6 and 39.9, Table 3). The species was also rare in a study using Onderstepoort light traps in the Netherlands, with a peak activity in early summer [64]. However, in a study from Germany in which midges were directly aspirated from animals (cattle, sheep) or collected in drop traps baited with these animals, $C$. pallidicornis was the second most abundant taxon after the Obsoletus complex 
(C. obsoletus, C. scoticus) [65]. The species was also identified as feeding on housed cattle [66]. Using light traps thus seems to largely underestimate the abundance of C. pallidicornis, as has been described for other species $[67,68]$. Thus, C. pallidicornis might play a role in BTV transmission at sites with high abundances, and further studies on the biology and the vector role of this species are required.

Overall, vector competence is only one of the several factors contributing to the vector capacity [69]. Others include abundance and biting rate. Thus, for example, although some species may have high competence rates, they do not serve as good vectors in the field if their abundance $(C$. bolitinos at lower altitudes in sub-Saharan Africa) [70] or biting rate (C. brevitarsis) [71] is low. On the other hand, a species with a low competence rate but high abundance (C. imicola and $C$. fulvus [70]; Obsoletus group [21]) represents a risk for BTV transmission. Therefore, in our studies, the high abundance of C. obsoletus and C. scoticus at lower altitudes suggests a considerable vector capacity for these species when infected with BTV-1 at lower temperatures (mean of $19{ }^{\circ} \mathrm{C}$ ), whereas C. grisescens, highly abundant at higher altitudes, cannot be considered a potential vector when infected with same BTV strain.

An explanation for the high $\mathrm{C}_{\mathrm{q}}$ values recorded in our experiments could be that only the heads were used to determine the viral dissemination but not the thoraxes containing the salivary glands as in other such studies [56, 72]. Another reason might be the incubation temperature (mean of $19^{\circ} \mathrm{C}$ ) and the relatively short incubation time of eight days. The latter was chosen because preliminary experiments with field-collected Culicoides had resulted in high mortality rates afterwards. However, an incubation time of eight days is in line with some previous work on Culicoides vector competence $[21,55,58,73]$. In addition, a previous study [36] on BTV dissemination in laboratory reared $C$. sonorensis incubated at $15{ }^{\circ} \mathrm{C}$ showed positive Culicoides at day 5 post-infection $\left(\mathrm{C}_{\mathrm{q}} 32\right)$, while no additional positive Culicoides were found from day 6 to day 30 post-infection.

Very few studies have been carried out assessing vector competence among field-collected Culicoides [27] and this is mainly due to the evidence that European Culicoides species are reluctant to artificially feed through membranes under laboratory conditions [70, 74]. As an alternative to membrane feeding, the use of cotton wool soaked with infectious blood has been evaluated. Although good feeding rates were achieved, the infection rates were significantly lower, due to the fact that smaller amounts of blood were engorged [75]. We evaluated different combinations of membranes, devices and attractants [46, 76, 77] (own data not shown), and eventually choose to use the feeding device previously described [39] but with Nescofilm50 MMx 40M as a membrane instead of chicken skin. Thus, feeding rates among field-collected Culicoides up to $52 \%$ were observed during the evaluation experiments; they varied between 14 and $27 \%$ in the vector competence experiments shown in this paper. Variations in feeding rates among populations of field-collected midges have to be expected as the individuals of these populations are of different age and gonotrophic status which may have implications on their predisposition to probe.

According to previous work on the Palaearctic species C. impunctatus [74], the length of storage before exposure to blood seems to crucially influence the feeding rates. Indeed, our own preliminary work (not shown) revealed that feeding the midges at days 2,3 or 4 post-collection (including $24 \mathrm{~h}$ of starvation) yielded lower feeding rates $(11 \%, 0 \%$ and $5 \%$, respectively) compared to feeding at day 5 as mentioned above.

Several studies described $37{ }^{\circ} \mathrm{C}$ as the optimal temperature for the infectious blood during artificial feeding of Culicoides [46, 76, 78]. In our experience, field-collected Culicoides exposed to a blood meal at this temperature barely took blood, and the mortality rate was increased. We therefore opted for lower temperatures of $25 \pm 4{ }^{\circ} \mathrm{C}$.

As shown in this paper, feeding rates were also higher when using less diluted blood meals (blood to virus-containing cell supernatant of 9:1, Table 2). However, we could not apply this ratio in our experiments as this would have excessively reduced the infectivity. Earlier studies have suggested minimal virus titres in the blood meals $\left(\mathrm{C}_{\mathrm{q}}\right.$ values below 30 per $\mu \mathrm{l}$ blood or a minimum of 5 $\left.\log _{10} \mathrm{TCID}_{50} / \mathrm{ml}\right)[49,79]$. Thus, $2: 1$ (BTV-4 and BTV-8) or 1:1 (BTV-1) ratios were used in our experiments to fulfil these requirements.

Although we are aware that when working with field Culicoides there are several parameters that can influence their survival rate (e.g. age, stress and dehydration during transportation, and other logistics), we would here like to describe interesting aspects that we observed during our studies.

First, the Culicoides populations fed on BTV-1 and BTV-4 had lower survival rates (Fig. 2) comparing to those fed on BTV-8, no matter the altitude from which they originated. We are not aware of any report on such virus-specific differences in survival rates of biting midges. Whereas a meta-analysis of studies revealed that arboviruses reduce the survival of their mosquito vectors [80], nothing is known in this regard to Culicoides. Survival rates of these vectors have been evaluated with two pathogens. Whereas the protozoon Haemoproteus induced high mortality in C. impunctatus [81], no effect was observed in $C$. imicola infected with a bacterium [82]. An unrelated effect of BTV infection was reported 
by McDermott et al. [83]. The eyes of $C$. sonorensis infected with BTV-17 were affected, leading to a change in field behaviour (but no information is given about survivorship).

Secondly, the Culicoides populations from the pre-alpine I area were the most robust, having a higher surviving rate no matter the virus strain used for their infection, while the Culicoides from the Swiss Plateau and the pre-alpine II areas had similar survival rates (Fig. 2). The reasons for this are obscure. A possible cause, a seasonal effect, can be ruled out as the midges from the two pre-alpine areas were collected during the same period (July-August) (and the midges from the Swiss Plateau area between June and October). The species compositions at the areas also cannot explain the differences: at the site with the highest surviving rate (pre-alpine I; Table 3) specimens of species belonging to the subgenus Avaritia (Obsoletus complex) and the subgenus Culicoides (mainly C. grisescens) were present in nearly equal numbers. At the Swiss Plateau site, the species of the Obsoletus complex dominated (Table 3), whereas at the pre-alpine II site there were only species of the subgenus Culicoides, mainly C. grisescens (data from the population dynamics study, to be published elsewhere). Thus, the species composition at the pre-alpine I area, where the midges had the highest survival rates, was in-between to the other populations.

\section{Conclusions}

To our knowledge, this is the first paper investigating the role of Culicoides for bluetongue virus transmission at high altitudes. We strongly confirm previous assumptions that C. scoticus is a highly suitable vector for BTV in Europe under cooler conditions. Our results have shown that in the pre-alpine regions, where C. scoticus is almost absent, there is no strong evidence to support viral dissemination efficiency of BTV. However, midges in these regions might be vectors of other pathogens: the highest known areas where seroconversion to Schmallenberg virus occurred were at altitudes above 1500 masl [84].

\section{Additional files}

Additional file 1: Figure S1. Culicoides feeding device. Culicoides are anesthetised at $-20^{\circ} \mathrm{C}$ for $2-3$ min and transferred moved into a "feeding chamber" (maximum 300 individuals/chamber) with Nescofilm50 MMx $40 \mathrm{M}$ (Alfresa Pharma Corporation, Osaka, Japan) membrane (a). The chamber is placed in a plastic cup containing heparinised bovine blood mixed with virus and a stirring magnet (b). The cup is covered with a lid (c) and placed in a glass bowl with (d) and placed on a heating magnetic stirrer (e). The insects were exposed for $30-45 \mathrm{~min}$ to a temperature of $25 \pm 4{ }^{\circ} \mathrm{C}$. (PDF $106 \mathrm{~kb}$ )

Additional file 2: Figure S2. Standard curves of all BTV strains used for oral infection of Culicoides. Conversion of viral RNA ( $C_{q}$ values) into PFU was determined for each serial dilution by RT-qPCR. (PDF $90 \mathrm{~kb}$ )

Additional file 3: Table S1. Viral RNA quantification cycles $\left(C_{q}\right)$ recorded from field collected Culicoides artificially fed with BTV-1, 4 and 8 spiked blood. Fully engorged Culicoides were incubated for 8 days in a climatic chamber under a fluctuating temperature regime (individuals with negative $C_{q}$ values are here not given). Their associated species name was confirmed by morphological features and by matrix-assisted laser desorption/ionization time-of-flight mass spectrometry (MALDI-TOF MS) or barcode sequencing. (PDF $20 \mathrm{~kb}$ )

\section{Abbreviations}

BTV: Bluetongue virus; $C_{\mathrm{q}}$ : Quantification cycle; CPE: Cytopathic effect; DMEM: Dulbecco's modified Eagle's medium; FCS: Foetal calf serum;

GMEM: Glasgow minimum essential medium; KC cells: Culicoides sonorensis embryonal cells; MALDI TOF MS: Matrix-assisted laser desorption/ionization time of flight mass spectrometry; masl: Meters above sea level; PFU: Plaque forming unit; RT-qPCR: Reverse transcription quantitative polymerase chain reaction; SBV: Schmallenberg virus; Vero cells: African green monkey kidney cells

\section{Acknowledgments}

We thank Jeannine Hauri, Mathieu Blaser and Uros Glavinic (Institute of Parasitology, University of Zürich, Switzerland) for valuable contributions to laboratory work; Beatrice Zumkehr, Andrea Vögtlin and Marco Alvez (Institute of Virology and Immunology, Mittelhäusern, Switzerland) for Vero cells and oligonucleotide supply; Simon Carpenter (The Pirbright Institute, UK) for KC cells supply; Massimo Palmarini (Glasgow University, UK) for supplying all the BTV strains; and Valentin Pflüger (Mabritec SA, Riehen, Switzerland) for MALDI-TOF analyses. We also thank the farmers (families Büche and Kindschi in Davos, families Margreth, Parpan and Wisler in the Lenzerheide region) for allowing us to set the traps at their premises and for their kind support. We highly acknowledge the financial support by the Swiss Federal Food Safety and Veterinary Office.

This manuscript represents the Doctoral Thesis of Anca loana Paslaru, veterinarian.

\section{Funding}

This study was funded by the Swiss Federal Food Safety and Veterinary Office (Grant no. 1.15.12) and the National Centre for Vector Entomology.

\section{Availability of data and materials}

The datasets used and/or analyzed during the current study are available from the corresponding author upon reasonable request. All data generated or analysed during this study are included in this published article and its Additional files.

\section{Authors' contributions}

AP performed the studies and processed the samples. AM contributed to the experimental design. PT carried out the statistical analyses. EV produced the experimental design and supervised the study. AP AM and EV were involved in writing the manuscript. All authors read and approved the final manuscript.

\section{Ethics approval and consent to participate}

Not applicable.

\section{Consent for publication}

Not applicable.

\section{Competing interests}

The authors declare that they have no competing interests.

\section{Publisher's Note}

Springer Nature remains neutral with regard to jurisdictional claims in published maps and institutional affiliations.

\section{Author details}

${ }^{1}$ National Centre for Vector Entomology, Institute of Parasitology, Vetsuisse Faculty, University of Zürich, Zürich, Switzerland. ${ }^{2}$ Section of Epidemiology, Vetsuisse Faculty, University of Zürich, Zürich, Switzerland.

Received: 22 March 2018 Accepted: 3 August 2018

Published online: 13 August 2018

References

1. Du Toit RM. The transmission of bluetongue and horse-sickness by Culicoides. Onderstepoort J Vet Sci Anim Ind. 1944;19:7-16. 
2. Purse BV, Carpenter S, Venter GJ, Bellis G, Mullens BA. Bionomics of temperate and tropical Culicoides midges: knowledge gaps and consequences for transmission of Culicoides-borne viruses. Annu Rev Entomol. 2015:60:373-92.

3. Mellor PS, Boorman J, Baylis M. Culicoides biting midges: their role as arbovirus vectors. Annu Rev Entomol. 2000:45:307-40.

4. Elbers ARW, Meiswinkel R, van Weezep E, Sloet van OldruitenborghOosterbaan MM, Kooi EA. Schmallenberg virus in Culicoides spp. biting midges, the Netherlands, 2011. Emerg Infect Dis. 2013;19:106-9.

5. Maan S, Maan NS, Ross-Smith N, Batten CA, Shaw AE, Anthony SJ, et al. Sequence analysis of bluetongue virus serotype 8 from the Netherlands 2006 and comparison to other European strains. Virology. 2008;377:308-18.

6. Wilson AJ, Mellor PS. Bluetongue in Europe: past, present and future. Philos Trans R Soc Lond B Biol Sci. 2009;364:2669-81.

7. Wouda W, Peperkamp NHMT, Roumen MPHM, Muskens J, van Rijn A, Vellema P. Epizootic congenital hydranencephaly and abortion in cattle due to bluetongue virus serotype 8 in the Netherlands. Tijdschr Diergeneeskd. 2009;134:422-7.

8. Elbers ARW, Backx A, Mintiens K, Gerbier G, Staubach C, Hendrickx G, van der Spek A. Field observations during the bluetongue serotype 8 epidemic in 2006. II. Morbidity and mortality rate, case fatality and clinical recovery in sheep and cattle in the Netherlands. Prev Vet Med. 2008:87:31-40.

9. Willgert K, Schroedle B, Schwermer H. Spatial analysis of bluetongue cases and vaccination of Swiss cattle in 2008 and 2009. Geospat Health. 2011;5:227-37.

10. Baetza HJ. Eradication of bluetongue disease in Germany by vaccination. Vet Immunol Immunopathol. 2014;158:116-9.

11. Zientara S, Sanchez-Vizcaino JM. Control of bluetongue in Europe. Vet Microbiol. 2013;165:33-7.

12. Sailleau C, Breard E, Viarouge C, Vitour D, Romey A, Garnier A, et al. Reemergence of bluetongue virus serotype 8 in France, 2015. Transbound Emerg Dis. 2017;64:998-1000.

13. Hornyak A, Malik P, Marton S, Doro R, Cadar D, Banyai K. Emergence of multireassortant bluetongue virus serotype 4 in Hungary. Infect Genet Evol. 2015;33:6-10.

14. Kiehl E, Walldorf V, Klimpel S, Al-Quraishy S, Mehlhorn H. Genebank accession numbers of sequences of Culicoides species vectors of bluetongue virus in Germany. Parasitol Res. 2009;105:293-5.

15. Mehlhorn H, Walldorf V, Klimpel S, Jahn B, Jaeger F, Eschweiler J, et al. First occurrence of Culicoides obsoletus-transmitted bluetongue virus epidemic in central Europe. Parasitol Res. 2007;101:219-28. Erratum in Parasitol Res. 2007; 101:833-4

16. Mehlhorn H, Walldorf V, Klimpel S, Schmahl G, Al-Quraishy S, Walldorf U, et al. Entomological survey on vectors of bluetongue virus in NorthrhineWestfalia (Germany) during 2007 and 2008. Parasitol Res. 2009;105:321-9.

17. Caracappa S, Torina A, Guercio A, Vitale F, Calabro A, Purpari G, et al. Identification of a novel bluetongue virus vector species of Culicoides in Sicily. Vet Rec. 2003;153:71-4

18. De Liberato C, Scavia G, Lorenzetti R, Scaramozzino P, Amaddeo D, Cardeti $\mathrm{G}$, et al. Identification of Culicoides obsoletus (Diptera: Ceratopogonidae) as a vector of bluetongue virus in central Italy. Vet Rec. 2005;156:301-4.

19. Savini G, Goffredo M, Monaco F, Di Gennaro A, Cafiero MA, Baldi L, et al. Bluetongue virus isolations from midges belonging to the Obsoletus complex (Culicoides, Diptera: Ceratopogonidae) in Italy. Vet Rec. 2005;157:133-9.

20. Mehlhorn H, Walldorf V, Klimpel S, Schmahl G. Outbreak of bluetongue disease (BTD) in Germany and the danger for Europe. Parasitol Res. 2008; 103(Suppl. 1):S79-86

21. Carpenter S, McArthur C, Selby R, Ward R, Nolan DV, Luntz AJM, et al. Experimental infection studies of UK Culicoides species midges with bluetongue virus serotypes 8 and 9. Vet Rec. 2008;163:589-92.

22. Kaufmann C, Schaffner F, Mathis A. Monitoring of biting midges (Culicoides spp.), the potential vectors of the bluetongue virus, in the 12 climatic regions of Switzerland. Schweiz Arch Tierheilkd. 2009;151:205-13.

23. Casati S, Racloz V, Delecolle JC, Kuhn M, Mathis A, Griot C, et al. An investigation on the Culicoides species composition at seven sites in southern Switzerland. Medi Vet Entomol. 2009;23:93-8.

24. Kaufmann C, Steinmann IC, Hegglin D, Schaffner F, Mathis A. Spatiotemporal occurrence of Culicoides biting midges in the climatic regions of Switzerland, along with large scale species identification by MALDI-TOF mass spectrometry. Parasit Vectors. 2012;5:246.

25. Tschuor AC, Kaufmann C, Schaffner F, Mathis A. Occurrence of biting midges (Culicoides spp.) at three different altitudes in an alpine region of Switzerland. Schweiz Arch Tierheilkd. 2009;151:215-21.
26. Casaubon J, Chaignat V, Vogt H-R, Michel AO, Thur B, Ryser-Degiorgis M-P. Survey of bluetongue virus infection in free-ranging wild ruminants in Switzerland. BMC Vet Res. 2013;9:166

27. Carpenter S, Veronesi E, Mullens B, Venter G. Vector competence of Culicoides for arboviruses: three major periods of research, their influence on current studies and future directions. Rev Sci Tech. 2015;34:97-112.

28. Perez JM, Garcia-Ballester JA, Lopez-Olvera JR, Serrano E. Monitoring bluetongue virus vectors in Andalusia (SW Europe): Culicoides species composition and factors affecting capture rates of the biting midge Culicoides imicola. Parasitol Res. 2012;111:1267-75.

29. Purse BV, Nedelchev N, Georgiev G, Veleva E, Boorman J, Denison E, et al. Spatial and temporal distribution of bluetongue and its Culicoides vectors in Bulgaria. Med Vet Entomol. 2006;20:335-44.

30. Mellor PS. Replication of arboviruses in insect vectors. J Comp Pathol. 2000; 123:231-47.

31. Purse BV, Mellor PS, Rogers DJ, Samuel AR, Mertens PPC, Baylis M. Climate change and the recent emergence of bluetongue in Europe. Nat Rev Microbiol. 2005;3:171-81. Erratum in Nat Rev Microbiol. 2006;4:160

32. Paaijmans KP, Imbahale SS, Thomas MB, Takken W. Relevant microclimate for determining the development rate of malaria mosquitoes and possible implications of climate change. Malaria J. 2010;9:196.

33. Carrington LB, Armijos MV, Lambrechts L, Scott TW. Fluctuations at a low mean temperature accelerate dengue virus transmission by Aedes aegypti. PLoS Negl Trop Dis. 2013;7:e2190.

34. Paweska JT, Venter GJ, Mellor PS. Vector competence of South African Culicoides species for bluetongue virus serotype 1 (BTV-1) with special reference to the effect of temperature on the rate of virus replication in $C$. imicola and C. bolitinos. Med Vet Entomol. 2002;16:10-21.

35. Carpenter S, Wilson A, Barber J, Veronesi E, Mellor P, Venter G, Gubbins S. Temperature dependence of the extrinsic incubation period of orbiviruses in Culicoides biting midges. PLoS One. 2011;6:e27987.

36. Veronesi E. Temperature and strain-related variation in the infection and dissemination of bluetongue virus in Culicoides (Diptera: Ceratopogonidae). London: PhD Thesis, Royal Veterinary College, University of London; 2012.

37. Fu H, Leake CJ, Mertens PP, Mellor PS. The barriers to bluetongue virus infection, dissemination and transmission in the vector, Culicoides variipennis (Diptera: Ceratopogonidae). Arch Virol. 1999;144:747-61.

38. Kaufmann C, Mathis A, Vorburger C. Sugar-feeding behaviour and longevity of European Culicoides biting midges. Med Vet Entomol. 2015;29:17-25.

39. Mathieu B, Cetre-Sossah C, Garros C, Chavernac D, Balenghien T, Carpenter $\mathrm{S}$, et al. Development and validation of IIKC: an interactive identification key for Culicoides (Diptera: Ceratopogonidae) females from the Western Palaearctic region. Parasit Vectors. 2012;5:137.

40. Dallas JF, Cruickshank RH, Linton YM, Nolan DV, Patakakis M, Braverman Y, et al Phylogenetic status and matrilineal structure of the biting midge, Culicoides imicola, in Portugal, Rhodes and Israel. Med Vet Entomol. 2003;17:379-87.

41. Folmer $\mathrm{O}$, Black M, Hoeh W, Lutz R, Vrijenhoek R. DNA primers for amplification of mitochondrial cytochrome c oxidase subunit I from diverse metazoan invertebrates. Mol Mar Biol Biotechnol. 1994:3:294-9.

42. Shaw AE, Ratinier M, Nunes SF, Nomikou K, Caporale M, Golder M, et al. Reassortment between two serologically unrelated bluetongue virus strains is flexible and can involve any genome segment. J Virol. 2013;87:543-57.

43. Nomikou K, Hughes J, Wash R, Kellam P, Breard E, Zientara S, et al. Widespread reassortment shapes the evolution and epidemiology of bluetongue virus following European invasion. PLoS Pathog. 2015;11:e1005056.

44. Veronesi E, Paslaru A, Silaghi C, Tobler K, Glavinic U, Torgerson P, Mathis A. Experimental evaluation of infection, dissemination, and transmission rates for two West Nile virus strains in European Aedes japonicus under a fluctuating temperature regime. Parasitol Res. 2018;117:1925-32.

45. Finney DJ. Statistical method in biological assay. 3rd ed. London: Charles Griffin \& Co.; 1978.

46. Venter GJ, Hill E, Pajor IT, Nevill EM. The use of a membrane feeding technique to determine the infection rate of Culicoides imicola (Diptera, Ceratopogonidae) for 2 bluetongue virus serotypes in South Africa. Onderstepoort J Vet Res. 1991;58:5-9.

47. Veronesi E, Mertens PP, Shaw AE, Brownlie J, Mellor PS, Carpenter ST. Quantifying bluetongue virus in adult Culicoides biting midges (Diptera: Ceratopogonidae). J Med Entomol. 2008;45:129-32.

48. Hofmann M, Griot C, Chaignat V, Perler L, Thur B. Bluetongue disease reaches Switzerland. Schweiz Archiv Tierheilkd. 2008;150:49-56.

49. Del Rio LR, Miranda MA, Paredes-Esquivel C, Lucientes J, Calvete C, Estrada $\mathrm{R}$, Venter GJ. Recovery rates of bluetongue virus serotypes 1, 2, 4 and 8 
Spanish strains from orally infected Culicoides imicola in South Africa. Med Vet Entomol. 2012;26:162-7.

50. Venter GJ, Mellor PS, Paweska JT. Oral susceptibility of South African stockassociated Culicoides species to bluetongue virus. Med Vet Entomol. 2006; 20:329-34.

51. Venter GJ, Wright IM, Del Rio R, Lucientes J, Miranda MA. The susceptibility of Culicoides imicola and other South African livestock-associated Culicoides species to infection with bluetongue virus serotype 8. Med Vet Entomol. 2011:25:320-6

52. Muller MJ. Experimental infection of Culicoides brevitarsis from south-east Queensland with three serotypes of bluetongue virus. Aust J Biol Sci. 1985; 38:73-7.

53. Tanya VN, Greiner EC, Gibbs EP. Evaluation of Culicoides insignis (Diptera: Ceratopogonidae) as a vector of bluetongue virus. Vet Microbiol. 1992;32:1-14.

54. Jennings DM, Mellor PS. The vector potential of British Culicoides species for bluetongue virus. Vet Microbiol. 1988;17:1-10.

55. Carpenter S, Lunt HL, Arav D, Venter GJ, Mellor PS. Oral susceptibility to bluetongue virus of Culicoides (Diptera: Ceratopogonidae) from the United Kingdom. J Med Entomol. 2006;43:73-8.

56. Veronesi E, Antony F, Gubbins S, Golding N, Blackwell A, Mertens PP, et al. Measurement of the infection and dissemination of bluetongue virus in Culicoides biting midges using a semi-quantitative rt-PCR assay and isolation of infectious virus. PLoS One. 2013:8:e70800.

57. Wittmann EJ, Mello PS, Baylis M. Effect of temperature on the transmission of orbiviruses by the biting midge, Culicoides sonorensis. Med Vet Entomol. 2002;16:147-56.

58. Jennings DM, Mellor PS. Variation in the responses of Culicoides variipennis (Diptera, Ceratopogonidae) to oral infection with bluetongue virus. Arch Virol. 1987;95:177-82

59. Foster NM, Jones RH. Multiplication rate of bluetongue virus in the vector Culicoides variipennis (Diptera: Ceratopogonidae) infected orally. J Med Entomol. 1979:15:302-3.

60. Mullens BA, Tabachnick WJ, Holbrook FR, Thompson LH. Effects of temperature on virogenesis of bluetongue virus serotype 11 in Culicoides varipennis sonorensis. Med Vet Entomol. 1995;9:71-6.

61. Wenk CE, Kaufmann C, Schaffner F, Mathis A. Molecular characterization of Swiss Ceratopogonidae (Diptera) and evaluation of real-time PCR assays for the identification of Culicoides biting midges. Vet Parasitol. 2012;184:258-66.

62. Balczun C, Vorsprach B, Meiser CK, Schaub GA. Changes of the abundance of Culicoides obsoletus s.s. and Culicoides scoticus in southwest Germany identified by a PCR-based differentiation. Parasitol Res. 2009;105:345-9.

63. Lehmann K, Werner D, Hoffmann B, Kampen H. PCR identification of culicoid biting midges (Diptera, Ceratopogonidae) of the Obsoletus complex including putative vectors of bluetongue and Schmallenberg viruses. Parasit Vectors. 2012:5:213.

64. Meiswinkel R, Scolamacchia F, Dik M, Mudde J, Dijkstra E, Van Der Ven IJK, Elbers ARW. The Mondrian matrix: Culicoides biting midge abundance and seasonal incidence during the 2006-2008 epidemic of bluetongue in the Netherlands. Med Vet Entomol. 2014:28:10-20

65. Ayllon T, Nijhof AM, Weiher W, Bauer B, Allene X, Clausen PH. Feeding behaviour of Culicoides spp. (Diptera: Ceratopogonidae) on cattle and sheep in northeast Germany. Parasit Vectors. 2014;7:34.

66. Ninio C, Augot D, Delecolle JC, Dufour B, Depaquit J. Contribution to the knowledge of Culicoides (Diptera: Ceratopogonidae) host preferences in France. Parasitol Res. 2011;108:657-63.

67. Carpenter S, Szmaragd C, Barber J, Labuschagne K, Gubbins S, Mellor P. An assessment of Culicoides surveillance techniques in northern Europe: have we underestimated a potential bluetongue virus vector. J Appl Ecol. 2008; 45:1237-45

68. Viennet E, Garros C, Gardes L, Rakotoarivony I, Allene X, Lancelot R, et al. Host preferences of Palaearctic Culicoides biting midges: implications for transmission of orbiviruses. Med Vet Entomol. 2013:27:255-66.

69. Scott TW, Takken W. Feeding strategies of anthropophilic mosquitoes result in increased risk of pathogen transmission. Trends Parasitol. 2012;28:114-21.

70. Venter GJ. Culicoides spp. (Diptera: Ceratopogonidae) as vectors of bluetongue virus in South Africa - a review. Vet Ital. 2015;51:325-33.

71. Standfast HA, Dyce AL, Muller MJ. Vectors of bluetongue virus in Australia. Prog Clin Biol Res. 1985;178:177-86.

72. Foxi C, Delrio G, Falchi G, Marche MG, Satta G, Ruiu L. Role of different Culicoides vectors (Diptera: Ceratopogonidae) in bluetongue virus transmission and overwintering in Sardinia (Italy). Parasit Vectors. 2016;9:440.
73. Veronesi E, Henstock M, Gubbins S, Batten C, Manley R, Barber J, et al. Implicating Culicoides biting midges as vectors of Schmallenberg virus using semi-quantitative RT-PCR. PLoS One. 2013;8:e57747.

74. Blackwell A, Mellor PS, Mordue W. Methods for enhancing the blood feeding response of field-collected Culicoides impunctatus (Diptera: Ceratopogonidae). J Med Entomol. 1996;33:504-6.

75. Venter GJ, Paweska JT, Lunt H, Mellor PS, Carpenter S. An alternative method of blood-feeding Culicoides imicola and other haematophagous Culicoides species for vector competence studies. Vet Parasitol. 2005;131:331-5.

76. Goffredo M, Romeo G, Monaco F, Di Gennaro A, Savini G. Laboratory survival and blood feeding response of wild-caught Culicoides obsoletus Complex (Diptera: Ceratopogonidae) through natural and artificial membranes. Vet Ital. 2004;40:282-5.

77. Barber J, Harrup LE, Silk R, Veronesi E, Gubbins S, Bachanek-Bankowska K, Carpenter S. Blood-feeding, susceptibility to infection with Schmallenberg virus and phylogenetics of Culicoides (Diptera: Ceratopogonidae) from the United Kingdom. Parasit Vectors. 2018;11:116.

78. Balenghien T, Pages N, Goffredo M, Carpenter S, Augot D, Jacquier E, et al. The emergence of Schmallenberg virus across Culicoides communities and ecosystems in Europe. Prev Vet Med. 2014;116:360-9.

79. Van Der Saag MR, Ward MP, Kirkland PD. Application of an embryonated chicken egg model to assess the vector competence of Australian Culicoides midges for bluetongue viruses. Med Vet Entomol. 2017;31:263-71.

80. Lambrechts L, Scott TW. Mode of transmission and the evolution of arbovirus virulence in mosquito vectors. Proc Biol Sci. 2009;276:1369-78.

81. Bukauskaite D, Bernotiene R, lezhova TA, Valkiunas G. Mechanisms of mortality in Culicoides biting midges due to Haemoproteus infection. Parasitology. 2016;143:1748-54

82. Morag N, Mullens BA, Gottlieb Y. Assessment of survival and body size variation of Culicoides imicola (Diptera: Ceratopogonidae) as functions of "Candidatus Cardinium" (Bacteroidetes) infection status. Appl Environ Microbiol. 2013;79:6260-3.

83. McDermott EG, Mayo CE, Gerry AC, Laudier D, MacLachlan NJ, Mullens BA. Bluetongue virus infection creates light averse Culicoides vectors and serious errors in transmission risk estimates. Parasit Vectors. 2015;8:460.

84. Rossi S, Viarouge C, Faure E, Gilot-Fromont E, Gache K, Gibert P, et al. Exposure of wildlife to the Schmallenberg virus in France (2011-2014): higher, faster, stronger (than Bluetongue)! Transbound Emerg Dis. 2017;64: 354-63.

Ready to submit your research? Choose BMC and benefit from:

- fast, convenient online submission

- thorough peer review by experienced researchers in your field

- rapid publication on acceptance

- support for research data, including large and complex data types

- gold Open Access which fosters wider collaboration and increased citations

- maximum visibility for your research: over $100 \mathrm{M}$ website views per year

At $\mathrm{BMC}$, research is always in progress.

Learn more biomedcentral.com/submissions 